\title{
Irish government under fire for turning back on basic research
}

\section{Letter from scientists questions commercially driven funding decisions.}

\section{BY DECLAN BUTLER}

$\mathrm{I}$ reland's drive to focus government research grants on areas that might create jobs and wealth is "short-sighted" and is destabilizing the country's basic-research fabric, say around 900 scientists in a letter to the Irish government. The call is aimed at changing the course of Ireland's national research strategy, which is currently under revision.

Research and innovation helped to fuel Ireland's economic boom in the 1990s. But growth slowed in the 2000s and the global financial crisis triggered a deep recession. Although total spending on research and development grew through the recession, helped by foreign investments, Ireland's government has cut state spending on research (see 'Celtic tiger tamed'). It also prioritized grants in 14 narrow areas -

ones in which either large global markets exist, or in which Irish companies are competitive. These include marine renewable energy, smart grids, medical devices and computing.

The effect has been to asphyxiate the many areas of fundamental science - including astrophysics, particle physics and areas of the life sciences - that have been deprived of funding, several researchers in Ireland told Nature. "The current policies are having a very significant detrimental effect on the health and viability of the Irish scientific ecosystem," says Kevin Mitchell, a geneticist who studies the basis of neurological disorders at Trinity College Dublin. "Research that cannot be shoehorned into one of the 14 prioritized areas has been ineligible for most funding," he says.

It does not help that funding sent directly to universities for research and teaching has dropped from $€ 1.4$ billion (US $\$ 1.48$ billion) in 2008 to $€ 940$ million last year, even as student numbers have increased. The number of government-employed research staff has also fallen over the past five years, particularly in areas that do not align with government priorities, adds Mitchell, who helped to organize the letter, sent to the government on 18 March.

"There are entire fields - such as neuroscience and evolutionary biology - for which no national-level funding is available in Ireland," says Kenneth Wolfe, an evolutionary biologist at University College Dublin who also signed the letter. Even leading researchers are feeling the pinch: those who have received funding from the European Research Council (ERC) - an

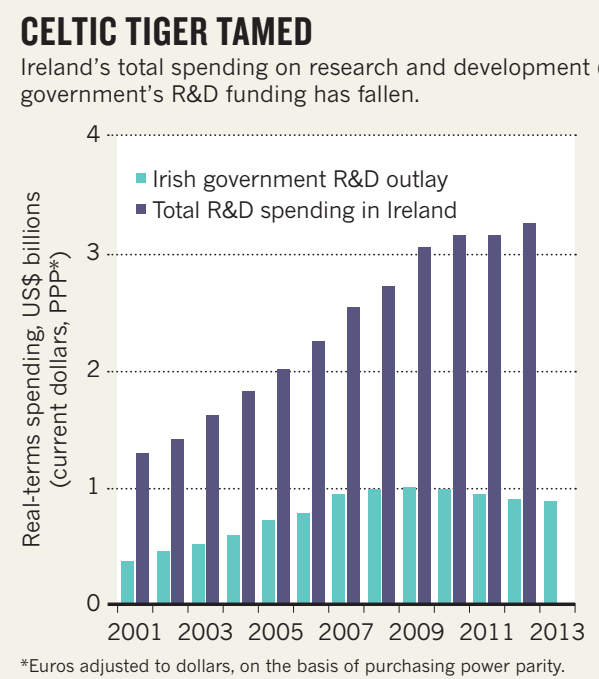

autonomous agency financed by the European Commission to fund the cream of basic research in Europe and beyond - say that they have trouble finding money at home. Wolfe, an ERC grant recipient, says that his nation's largest research-funding agency, Science Foundation Ireland (SFI), has the attitude that "if you want to work in a non-priority field, you should go off and get ERC funding. But the ERC is not supposed to be a substitute for national infrastructure." Even in the 14 priority areas, grant proposals are not judged on scientific excellence alone, says Mitchell. After the usual peerreview process, proposals are assessed for their potential commercial and economic impact by a panel of business people.

\section{BACK TO BASICS?}

"Research prioritization was formulated in response to unprecedented economic circumstances in Ireland," says Orla Feely, vicepresident for research, innovation and impact at University College Dublin. The policy has had successes, she says, but it has also created gaps in Ireland's research landscape. Although Ireland should still identify and prioritize areas in which it could lead internationally, she says, it is "crucial for long-term competitiveness" that the country maintains a strong science base that emphasizes excellence in all areas of research.

The letter comes as Ireland's ministry for jobs, enterprise and innovation is publicly consulting on a new five- or six-year national

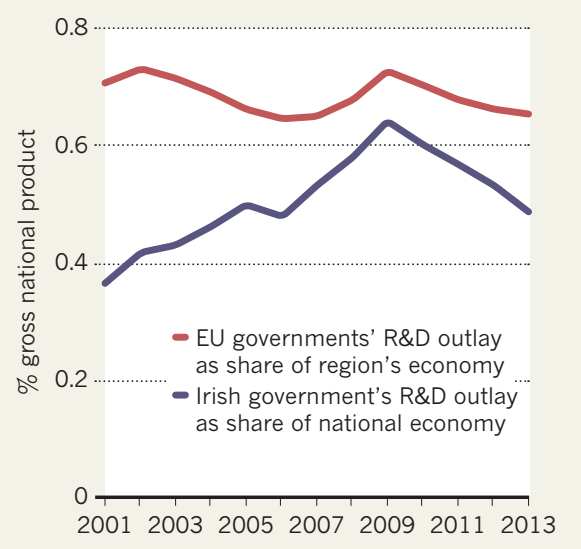

strategy for science, technology and innovation, which is scheduled to be published this year. A discussion document for the consultation, which closes on 23 March, explicitly states that "research prioritisation" will set the agenda of the strategy, and remains a main national goal.

Mark Ferguson, director-general of the SFI and the country's chief scientific adviser, says that a small country such as Ireland (its population is around 4.6 million) cannot afford or expect to be a world leader in all fields of science. "But it definitely wants to be world class in as many fields as possible, particularly those of key relevance and opportunity for the future," he says. The SFI advocates for increased funding in select areas of research and development, but also for greater private funding, he says.

"In the context of our ongoing fiscal constraints and the many competing demands for investment of public funds, the government will continue to support excellent and impactful research across the continuum, from basic to applied," said a spokesperson for the innovation ministry.

The letter's signatories say that they appreciate the need for priorities and for research that helps to provide economic return. But the new strategy should guarantee adequate investment across all scientific disciplines, says Mitchell, and grants should be assessed on their scientific merit alone. Without fundamental research, the letter says, "there will be no discoveries to capitalise on". 